\title{
The Alternative to Post-Hegemony: Reproduction and Austerity's Social Factory
}

\author{
By Kylie Jarrett
}

\begin{abstract}
In the transitions to advanced liberal States and post-Fordist economic paradigms, it is argued that the distinction between work and sociality has become blurred. This marks the emergence of the "social factory" where sociality is industrialised and industrialisation has become increasingly centred on immaterial, social activity. It is further argued that this regime has generated a new articulation of socioeconomic relations based on biopower and systems of control alongside the irruptive agency of multitude. Consequently, it is often suggested that the concept of hegemony can no longer adequately explain manifestations of power and resistance. The argument is that we live today in a state of post-hegemony. This paper challenges the theoretical and pragmatic underpinnings of this position at a number of levels, arguing that the lived politics associated with the imposition of Austerity economics across Europe, but particularly as manifest in Ireland, undermine the assertion that hegemony is no longer a relevant conceptualisation of power dynamics. In particular it uses feminist thinking to challenge the epochalisation inherent to arguments of post-hegemony, arguing instead for a return to engagement with the reproductive logic of hegemonic discipline.
\end{abstract}

Keywords: Immaterial labour, hegemony, activism, feminism. 


\section{Introduction}

When global financial markets collapsed on their ephemeral underpinnings in late 2007 for some this was the inevitable exposure of capitalism's contradictions and limits. It was hoped by many on the political Left that from the ensuing fiscal crisis would emerge an alternative economic or, ideally, social system. I write this though from Ireland in 2013 where this is far from the case. Instead of life in a new socialist utopia, Irish citizens struggle under imposed 'austerity measures' that in six years have reduced available public funds by $€ 28.5$ billion through spending restrictions and the introduction of taxes, levies and charges (The Irish Times 2013). These cuts have been made in order to service a socialised debt accrued by State guarantees of failing private enterprises within the Irish banking and finance sectors.

Dominant in the public discourse of Austerity Ireland is the primacy of 'fixing the economy' over and above all other concerns such as social welfare, public service provision or social equity. Perverse pleasure is taken in receiving positive commentary in the quarterly compliance reviews of the European Union/International Monetary Fund/European Central Bank (the Troika) that have overseen the imposition of Austerity (a nominalised agent in most discourse, hence the capitalisation). Through a 'successful' return to international bond markets in July 2012, Ireland has become the poster child of the wider Eurozone's resilience and model for the effectiveness of Austerity in restoring stability to national markets.

However, the effects of these measures on individuals, communities, or Irish society are not commonly encountered in political discourse (Titley 2013). This is despite Irish Central Bank figures indicating that 1 in 10 homeowners are in financial distress and facing repossession (The Irish Times 2012; Pope 2013), where already mismanaged public services such as health and education are unable to function effectively in their reduced budgets (Burke 2010) and where reductions in social welfare payments and services to vulnerable citizens such as carers, the disabled and the unemployed have increased levels of poverty and deprivation (Caritas Europa 2013). A survey by international charity Oxfam (2013) indicated that in 2012 one in four Irish people were left with $€ 100$ or less each month after covering necessary bills, taxes and charges, with a further 602,000 left with no disposable income at all.

While there is public protest against these measures and the socialisation of debt more generally, political unrest in Ireland has been muted compared to other countries in which similar Austerity models are being instituted. Writing in the Greek Left Review, Irish academic Helena Sheehan describes Greek protestors chanting, 'We are not Ireland. We will resist', commenting: 'It stung. Those of us who are resisting felt acutely our failure to mobilise sufficient numbers to put up 
the resistance the situation required' (2013: n.p.). There seems little but the orthodoxy of neoliberal finance capitalism at play in mainstream Irish politics.

In coming to terms with these events in my adopted nation, I increasingly need to invoke the concept of 'hegemony'. Only the maintenance of some generalised consent explains the widespread compliance with the regime of Austerity recognised by Sheehan. However this runs counter to various contemporary theoretical trends shaped by insights of Michel Foucault and Gilles Deleuze, but particularly as articulated in the work of Michael Hardt and Antonio Negri, in which hegemony has been relegated to a historical footnote, supplanted by regimes of biopower, systems of control and the dynamics of communicative capitalism. It is argued that in the 'social factory' of biocapital, in which the boundaries between life/culture and alienated labour have been blurred, also lie re-organised political economy and governance systems beyond power exerted through mechanisms that sustain hegemony. According to this argument, today we live (and theorise) in a state of 'post-hegemony', where biopower is exerted through mechanisms of immanent communication rather than disciplining discursive representation and in which the articulation of difference associated with counter-hegemony has been defused as a form of political resistance (for instance Swiffen 2009; McStay 2011; Beer 2009; Arditi 2007). It is presumed or argued that the concept of hegemony has lost its purchase and can no longer serve as an explanatory tool for how power and/or social antagonism manifests.

Contrarily, I suggest that we cannot fully understand, and therefore intervene, in contemporary political economies and societies unless we take into account the reproduction of dominant dispositions, ideologies and through that, the maintenance of the capital relation. We cannot engage politically unless we factor in the disciplinary reproductive logic of hegemony. This paper will therefore criticise the concept of post-hegemony as articulated within discussions of the social factory, multitude and regimes of biopower. In particular it will focus on the epochalisation inherent to these arguments that obscures the long history of the exploitation of biopower. This aspect of my argument draws on feminist insights into the importance of reproductive labour, and takes inspiration from Angela Mitropolous' (2012) underscoring of oikonomia and generational lineage, in order to reassert the role of hegemonic reproduction in the social factory. While not seeking to resolve the problems of how best to generate counter-hegemonic resistance, struggles over Austerity in Ireland will be used as an example of how understanding hegemony continues to be a vital tool for an engaged politics.

\section{Biopolitics and the Social Factory}

Foucault's discussion of the emergence of biopower, articulated in the threevolume History of Sexuality (1976/1998: 1984/1992: 1984/1990) and in lectures given at the College de France in the late 1970s (2008), is the axis from which 
arguments about the contemporary social factory and post-hegemonic power have been spun. Foucault traces the emergence of a form of governance based not in the right of seizure exerted by a sovereign power but in the administration, management and optimisation of populations conceived as a social body. This power works through two techniques. The first is associated with disciplining the capabilities of the machinic body (emphasising individual corporeality) to maximise its capabilities. The second is focused on the supervision of the 'species body', effected through series of interventions and regulatory controls at the level of the population (Foucault 1976/1998). Foucault associates biopolitics with the development of liberalism as a framework of governance and with the emergence of modern biology and its notions of 'self-regulation and self-preservation' (Lemke 2011: 48). In particular, he emphasises the importance placed on 'human capital' within the economic logic of neoliberalism and the consequent focus of social and cultural policies such as education on 'the more or less voluntary formation of human capital in the course of individual's lives' (Foucault 2008: 228). It is through mobilisation of both these techniques for exerting power that life processes, intimate interpersonal behaviour and individual morality have become legitimate and viable objects of socio-political intervention and been incorporated into systems and techniques of governance.

While the concept of biopolitics has been developed or used variously in divergent fields (Lemke 2011), relevant for this paper is the relationship of a Foucauldian inflected concept of biopower to contemporary Marxist critiques recognising the increasing importance of immaterial, affective, communicative and/or cognitive inputs in the circuits of capital. Many Marxist theorists associated with the Autonomia political movement and theoretical paradigm, but in particular Hardt and Negri (2000: 2005: 2009), mobilise a similar understanding of the incorporation of life into mechanisms of power. Mario Tronti's term 'the social factory' is used to describe the conclusion of developments associated with postFordism through which various life processes, once deemed exterior to the commodity relation, have become integral to the economic calculations of capital (Negri 1989). Maurizio Lazzarato (1996) offers the examples of software, audio/visual production and advertising as emblematic industries where the cognitive and affective investments of workers and consumers alike add intangible value to commodities. The socially meaningful practices of digital media consumers of products such as YouTube, Facebook or computer games exemplifty this trend as these constitute unpaid content, but also generate revenue through transformation into consumer data that is extensively mined and sold to advertisers in the form of the audience-commodity (Terranova 2000; Fuchs 2008; Dyer-Witheford \& de Peuter 2009). This industrialisation of sociality also takes the form of the 'presence bleed' associated with mobile communications technologies that blur boundaries between work and intimate personal life (Gregg 2011). It can also be found in the logic of 'workfare' programmes, lifelong training initiatives and in 
the expanding phenomenon of unpaid corporate internships (Ross 2013). In these instances, often pleasurable and (quasi-) voluntary social activity manifests the alienating, expropriating and commodifying logics of industrial capitalism (Negri 1989).

The social factory is also associated with the socialisation of industry in that there is an increasing reliance on social relationships and cognitive capabilities within factory walls. Great importance is attributed to non-material processes such as communication and affective interaction in the contemporary workplace. This is recognised in economic calculations of 'human capital' that include the intellectual and affective property embodied in the capacities of workers. Even in manufacturing and primary industries, increasing computerisation of industrial processes has foregrounded so-called 'soft' skills, particularly those associated with symbol manipulation, intellectual achievement and interpersonal communication. In this context, labour-power (as potential energy) is no longer only associated with the force of the living body but with subjectivity, cognition and affect (Virno 2004). This incorporation of social skills into capital in both traditional leisure and paid work contexts signals the increasingly blurry boundaries between sociality and industrialised processes. As Dyer-Witheford summarises the 'world of the socialized worker is thus one where capital suffuses the entire form of life' (1999: 81).

The concept of the social factory describes the logic of the 2013 Irish tourism initiative The Gathering (http://www.thegatheringireland.com/), designed by the State to attract the tourism and investment dollars of the broad Irish diaspora. This campaign encouraged communities and individuals to create events to be attended by international guests or visiting expatriates, attempting to enrol the entire population in crafting an entertaining celebration of normative Irish culture and traditions. The tag line of the campaign - 'invite them home' - directly refers to interpersonal relationships. In doing so, it encapsulates the incorporation of sociality within a national economic plan to increase tourism numbers and generate domestic employment in tourism-related ventures, as well as to build potentially lucrative business linkages. According to government data released at the Irish Economic Forum (Merrionstreet.ie 2013), tourism numbers grew by an extra 291,000 visitors between January and August of 2013, up 6.5\% from the same period the previous year. This included an increase of $16.5 \%$ in US visitors, most closely associated with the Irish diaspora. Noted in the report were business opportunities emerging from strengthened links with this diaspora and also increased civic pride and social capital, with ' $73 \%$ of those polled said organising a Gathering had inspired people to work together to the benefit of the community'. In its intermingling of interpersonal relationships and social and community cohesion with quantified assertions of economic value, The Gathering embodies the subsumption of the entire Irish social body into a capitalist logic. 
But in contemporary Ireland it is in Austerity that the social factory is exemplified. This regime blurs life and work not only by demanding an effective extension of the working day as each individual labours for less pay and/or longer hours, regardless of productivity. Its logic also permeates non-work aspects of life from the biological - as public medical care becomes more expensive or laborious to access due to cuts in medical services - to the affective - as family-based care labour becomes pressured by cuts to carer allowances and respite care facilities, the imposition of longer working days, and reduction of real incomes through increased taxation and charges. Through claims by current Taoiseach (Prime Minister) Enda Kenny that 'we went mad borrowing', or those by former Táinaiste (Deputy Prime Minister) Brian Lenihan that 'we all partied', individual consumption decisions, coded as moral choice, become the collective cause and, by implication, the solution to the economic crisis (see Kennedy 2011; Titley 2013). Indeed the cultural 'morality' of various indebted states has become a key component of recent European governance in which countries involved in bailouts are represented as having immature cultural systems that promote irresponsibility and idleness (Mylonas 2012). A commitment to probity across all facets of life, to stoicism in the face of physical and/or emotional pain, is demanded by Austerity economics. Austerity is a 'whole of life' phenomenon. Austerity is the social factory.

\section{The End of Hegemony?}

Despite the relationship to state economics depicted here, the social factory is nevertheless associated with the decline of power exerted as hegemony. As Negri writes, the socialised worker is 'a producer, but not only a producer of value and surplus value; s/he is also the producer of the social cooperation necessary for work' (1989: 80, original emphasis). Drawing on Marx's notion of the general intellect, Hardt and Negri (2005; 2009) expand upon the agency of this cooperation, attributing a degree of autonomy and immeasurability to social production that generates powerful tensions in the processes of capital (2009: 270). There is therefore a contradiction between the needs of capital and the qualities of socialised labour, and it is from this tension that Hardt and Negri generate their optimistic view of the radical potential of such work. They suggest that the excessive energies associated with cooperative, socialised production may manifest as a multitude - a heterogeneous collectivity - with the power to generate a common pool of knowledge and most importantly activity in contradiction of capitalist structures. Biopower can thus be associated with the systems of population management identified by Foucault but also with the emergent, potentially transformative agency of workers: it is implicated in radical critiques and political activism as much as with fears of containment and contamination by corporate and state interests. 
The political agency, and management, of multitude is typically associated with regimes of post-hegemonic control rather than regimes of hegemonic domination. Deleuze's (1995) reflections on the politics of control have been central to this position. He argues that contemporary social systems are 'no longer exactly disciplinary' (1995: 174) in that they do not operate through confinement but instead through constant communication that generates a system saturated with the dictates of power - a state of control or, as Hardt and Negri would suggest, Empire (2000). Deleuze's position underpins Nicholas Thoburn's (2007) advocacy of a post-hegemonic Cultural Studies. Drawing on the work of Laclau and Mouffe, Thoburn typifies hegemonic power as the construction of a system of equivalences that are always only partial. This in turns suggests the potential for transformative politics in the creation of alternative or broader chains of equivalence within the network of relatively autonomous social relations that constitute the realm of politics. However, for Thoburn, this model fails to appreciate the concept of the social factory and its negation of the relative autonomy of social spheres and, subsequently, the potential for alternative politics to emerge from the cultural and social superstructure (see also Swiffen 2009). He argues that social change can only emerge from critical interrogation of, and changes to, the relations of production such as those associated with multitude rather than from changes in structuring discourses as in counter-hegemonic resistance.

Other arguments about post-hegemony draw on the distinction Foucault makes between disciplining techniques and the techniques of biopower in The History of Sexuality. Scott Lash (2007) outlines the qualities of this 'mutation' in the exertion of power. He claims that the extensive politics of hegemony have given way to a politics of intensity characterised by four key qualities. The first is a transition from the epistemological regime, where hegemony was enacted through the Symbolic realm in the form of discourse, to an ontological regime of power. Domination, and resistance, Lash says, increasingly occur in the Real, which is 'not at all knowable through cognitive judgement' (58) but only through intensifications of affect. Consequently, the ontological being is no longer only a site of resistance but also one of domination. 'In the age of hegemony, power only appropriated your predicates: in the post-hegemonic present it penetrates your very being. Power, previously extensive and operating from without, becomes intensive and now works from within' (59).

Following from this is Lash's related argument that there has been a shift from a regime of 'power over' to 'power as generative force'. Here he draws on Hardt and Negri's use of the term 'potentia' to describe power associated with 'force, energy, potential', indeed with life itself (59). This self-organising vitalism is that captured within the biopolitics of immaterial labour, as well as with multitude as a political force. Rather than being imposed from above as in hegemony, power 'comes to act from below: it no longer stays outside that which it "effects". It becomes instead immanent in its object and its processes’ (61). In post-hegemonic 
contexts, power's determining ethics are therefore generated from inside the empirical facticity of the Real and the vitalism of the body. Accordingly, and related to Derrida's argument, Lash suggests there has been a shift from an extensive politics of collective representation based in the normative models of the Symbolic to a regime of immanent, intensive communications. Power is not enabled by discursive representation of its legitimacy but through the immediacy of the performance of its functions in a society of control in which distinct spaces of discipline have collapsed. It functions through a 'reflexive and autopoeitic self-production' (Lash 2007: 66; McStay 2011) that is chronically generative of social order. Thus, in Lash's estimation, although 'it takes place increasingly through the media, domination was never so immediate. So unreflective. So without a separate sphere of discursive legitimation' (2007: 66).

\section{Hegemony in Practice}

Upon completion of his description of the mechanisms of post-hegemonic power, Lash notes: 'The observations above do not really do justice to the power-ashegemony position' (68). In the context of his argument, this acknowledgement is curious but it is accurate. As Johnson (2007) argues, the description of posthegemony Lash and others espouse inadequately represents the complexity of society even while drawing important features of post 9/11 societies into a theoretical frame. What puzzles Johnson is that the end result of this theorising 'is viewed as the end of hegemony rather than as a new hegemonic moment' (2007: 102). I have the same concern that these conceptualisations inadequately capture the ways power in practice continues to mobilise disciplining discourses to sustain hegemonic ideologies. On a pragmatic level, it seems difficult to understand both the politics of Austerity and the resistance to it emerging across Europe without recourse to the idea of hegemony, and in particular without referring to the construction of alternative discursive formations. An example from Ireland will illustrate.

Central to the politics of the Irish Austerity State is the argument that 'there is no alternative' (TINA) to Austerity generally and, more recently, to the reduction of public sector costs in order to meet budgetary benchmarks imposed by the Troika. Thatcher's famous but simple expression of assumed consensus has widespread purchase across the Irish media and in public discourse, appearing explicitly and implicitly in the lead-up to Budget announcements, in the limited discussions around debt default or in the general framing of the decision to socialise bank debt (Politico.ie 2010; Brennan 2010). The constant reiteration of TINA naturalises debt and Austerity measures as simple 'common sense', part of the organic background of contemporary politics and thus beyond critique. Consequently all questioning of Austerity, and even of particular measures, is cast as irrational. As Titley (2013) describes, dissent or the proposition of alternatives is 
constructed as taboo for it is seen to dent market confidence, raise spectres of unrest and show a limited grasp of reality. In political discourse in Ireland, to question the imposition of Austerity is simply not sensible.

That there is no alternative to Austerity can only be described as a hegemonic discourse and arguably the hegemonic discourse of contemporary Ireland - Titley refers to it as the 'ur-mantra' (2013: 199). This normalising and normative declaration of 'common sense' establishes a singular view of economic circumstances and solutions, renders contrary positions illegitimate, and in turn legitimates material manifestations of social power by the Irish State and its agencies. This declaration has material effects as it is the logic upon which the social and economic order is organised, providing the legitimating framework for a series of brutal national Budgets that have had very real consequences for individual citizens and the social fabric. At the same time, it is also encountered repeatedly at a representational level in the discourse of media commentators, politicians and of the general population who, even while rejecting particular economic proposals, nevertheless accept that cuts must be made. Contrary then to arguments that control is exerted in the social factory only and primarily through the Real, power exerted through symbolic means is also alive, well and effective in Austerity Ireland.

The discursive properties of power relations are also demonstrated in acts of resistance. In 2013, an alliance of public sector workers emerged in Ireland challenging the imposition of another reduction in wages and, importantly, further degradation of labour conditions. This coalition was constituted by emergency service and health care professionals involved in the 24/7 Front Line Services Alliance, various groups of educators, and diverse sets of office workers associated with the Services Industrial Professional and Technical Union. It set out to mobilise workers to reject an agreement between the government and public sector unions that traded continuing employment security for increased hours, reduced conditions and direct pay cuts. Coming after a previous reduction of wages and conditions, the goal of this proposal (to which, it was claimed, there was no alternative) was to save a further $€ 1$ billion from the public sector pay bill by 2015 .

Contrary to the positions of their own union executives, this coalition of rankand-file union members not only argued for rejection of the proposal on economic grounds, but also articulated an alternative narrative about the nature of the cuts. Protest was articulated around principles of collective solidarity - 'Do not vote for someone else's pay cut' become one of the rallying cries - and groups were united in a refusal to accept that these cuts were an indisputable necessity. The effects of reduced conditions on the ability of public sector workers to actually serve the public, an argument absent from formal and mediated discussion of the proposals, also became a feature of these protests (for instance, Workers' Solidarity Movement 2013). While the position taken by this coalition did not challenge a key structural feature contributing to Austerity - the socialisation of private bank debt 
- its defiance of the consent assumed in TINA, along with its emphasis on social effects, marks a war of position with dominant ideas.

This coalition bears some of the characteristics of multitude in that this is a temporary, irruptive alliance of emergent, grass-roots movements with a diversity of politics and goals. But this heterogeneous multitude was nevertheless an organised coalition who actively sought solidarity between varied union members and temporary points of consensus from which an alternative narrative was generated. Organisers used social media and face-to-face meetings to articulate their point of difference from institutionalised discourses and this 'old-fashioned' grass-roots campaign was initially successful, with a wide spread rejection of the proposal across many unions in the ratification vote. In light of this organised resistance, the government was forced to re-enter negotiations with unions, producing yet another proposal marginally reducing the cuts and changes to conditions. At the same time though, the State also engaged in an overt exercise of symbolic violence, successfully passing legislation to impose by fiat greater pay cuts and reduced conditions upon members of any union who failed to vote for acceptance of the revised proposals. Confronted with this aggressive tactic, it is perhaps no surprise that in a second vote in September 2013 all public sector unions except one ratified the proposal.

Even though emerging from Austerity Ireland's social factory, this alliance of public sector workers is comprehensible only as an example of counterhegemonic agency. In the context of TINA, the quite literal withdrawal of consent to the further imposition of Austerity measures by public sector workers was the manifestation of a direct challenge to the hegemonic logic of the Irish State. By also attempting to shift the discourse to questions of the effect on public services such as health, education and policing, this coalition proposed a new framework for conceptualising Austerity. That the government was forced into an overt exertion of its coercive power in order to counter the growing validity of this counterhegemonic position indicates not only the existence, but also the effectiveness and viability, of counter-hegemonic organised action. The degree of symbolic violence needed to repress this resistance shows this protest to be a small victory for anti-Austerity campaigners, albeit a pyrrhic one.

This example also emphasises the importance of activism in relation to symbolic dominance. Even agreeing with Thoburn and Deleuze that the important site of struggle is production relations does not preclude the existence of various cognitive, discursive and affective structures that materially support those relations, and as such may serve as important sites for marshalling resistance. The struggle of Irish public sector workers is certainly over material conditions but just as certainly contains symbolic dimensions. The shift from framing reductions in labouring conditions as an indisputable economic necessity to an unnecessary, socially damaging intervention continues in the ongoing industrial action by the only union to reject the revised agreement - the Association of Secondary Teachers, Ire- 
land (ASTI). Despite Government threats of compulsory redundancies for unionised workers, and a concerted mediated campaign to describe this resistance as socially irresponsible (see Malone 2013; O’Regan 2013; O’Rourke 2013 for example), ASTI members and their supporters continue to point to the detrimental effects of the demanded reforms on the education of young people (Wall 2013; McGuire 2013; Dunphy 2013). In this example, the struggle may be occurring in the Real and is about material conditions, but it also contains non-material, cognitive elements that are primarily about redefining the meaning of Austerity. How much purchase these counter-hegemonic arguments will secure in the long-term is unknown, but currently they are serving as an anchoring and rallying point for this particular struggle to change material conditions.

In other national contexts, the practicalities of resistance can similarly be associated with counter-hegemonic struggle. Costas Douzinas' (2010: n.p.) description of the 2008 anti-austerity 'riots' in Greece as an 'event' fundamentally other to 'politics as usual' draws on ideas of multitude. Nevertheless he still claims that the continued effectiveness of this campaign relies on a return to more traditionally organised political negotiation by a vanguard, albeit with 'new politicised subjects and the re-arrangement of the rules of political participation' (n.p.). After the irruptive power of multitude, real political change requires engagement with some organisational structuring, including leaders charged with articulating a counterhegemonic position (Thorburn 2012). As Couze Venn suggests about other plural political movements: 'A sense of hegemony and counter-hegemony is still ambivalently at work ... motivated by the exigencies of practical politics' (2007: 122). It is at this practical level of heterogeneous anti-Austerity political activity - where actors must organise against prevailing ideologies and structures - that the concept of post-hegemony fails to offer a convincing interpretive framework.

\section{The Problem of Consent}

This inability to capture lived reality lies in the failure to address in the foundational principles of post-hegemony the question of consent and how that is secured or lost. What is typically described instead is totalising domination by the constant communication of a biopolitical machine. This is Lash, Thoburn and Deleuze's position for instance, but when placed in the context of even the limited Austerity protests described above, this does not make sense. While the TINA discourse may penetrate the entire social body, it cannot be evenly distributed. If there was only a regime of control, protest such as that of the Irish public sector workers could never emerge. Indeed, it is difficult to understand how the agency of multitude is ever able to actively generate a counter politics unless the illegitimacy of dominant conditions is first experienced and alternative modes made conceivable, forcing irruptive energy in particular directions. 
Unless a population has been rendered entirely passive, the stability of even a pervasive system of control, such as that associated with biopolitics, needs to be reproduced and perpetually secured. Without such mechanisms for establishing consent, or for imposing discipline where consent is not forthcoming, there is only power's exhaustive penetration that in turn leaves limited or no capacity for resistance of the type emerging across European states. In Austerity Ireland, the constant repetition of TINA is one such tool, asserting a culturally desirable social position, and, in casting alternatives as absurd, providing negative reinforcement as well. It simultaneously assumes hegemony, and asserts discipline. In Lash's argument however, a close correlation is drawn between social reproduction, disciplining and hegemony at the same time as this is rejected in favour of what can best be described as an immanent subjectivation at the level of the individual body and Self. However, there seems little difference between the post-hegemonic subject for whom legitimation 'is no longer separate from what it is meant to legitimate, it becomes automatic' (Lash 2007: 66) and the disciplined subject who has internalised social norms so that they align themselves voluntarily with the needs of power. Lash's depiction ignores Althusserian insights and (mis-) represents hegemony as a form of domination always imposed by external institutions rather than as an effect of subjectivities fundamentally shaped by the interaction between each socialized individual, their affective and biological propensities and the normative structures of their contingent sociopolitical context.

Thus, while biopower may work to 'establish life and to penetrate all of its aspects in order to rule it' (Atzert 2006: 63), the properly Foucauldian, or perhaps Weberian, question of what brings an individual to accept domination by any governance structure must still be asked. If the exertion of power is to be made sensible and/or contestable there must be mechanisms that legitimate, or fail to legitimate, the exploitation of an individual's biopower so that an individual or group can become complicit with, or seek to challenge, that relation. Consequently, determining what discursive mechanisms secure consent, particularly at the level of disciplined subjectivity, and how they may be disrupted remains a core political project, but one that cannot be articulated in the framework provided by post-hegemony.

\section{Continuity of Hegemonic Discipline}

It is notable that most articulations of the post-hegemonic position were published in 2007, just before the global financial collapse and the imposition of new sociopolitical-economic regimes of Austerity across a variety of advanced liberal countries. The post-crash moment though is marked by overt mechanisms for asserting and securing the social order and greater, more obvious struggles of position such as those manifesting in the alliance of Irish public sector workers and, in particular, in the use of legislation to quash this protest. But as this example also demon- 
strates, there are multiple forms and gradations of control simultaneously being effected within Austerity states. Both coercive policing (punitive legislation) and subjectivation at the symbolic level (TINA) are being used to sustain hegemony. The systems of communication and affect described by Lash and Thoburn are also in play - the extensive penetration of TINA works at the level of fear - but these are merely the mobilization of one suite of techniques working alongside, sometimes in opposition, sometimes in concert, with hegemonic discipline, counterhegemonic articulations of difference, and the imposition of coercive violence. Thus while the techniques, goals and struggles of any given socio-political, economic or cultural moment may take on new contours, and the particular qualities of the ideal subject shift in accordance, this does not mean the end of political domination through hegemonic discipline (in whatever multiple forms that may take).

It is this continuity between hegemonic discipline and the conditions of the biopolitical social factory that I wish to underscore as I draw attention back to the reproductive logic of power relations and the necessity of understanding those in order to generate alternative political positions. Such continuity is rarely recognised for a key assumption of post-hegemony theories is of an epochal change from hegemonic regimes of symbolic domination to post-hegemonic regimes of biopolitical control. Indeed, it is only in the maintenance of the idea that there has been such a seismic shift that allows for the claim of a fundamentally transformed relation of power and the insistence on this as post-hegemonic. As both Mitropoulos (2012) and Thomas Lemke (2011) argue, this is contrary to Foucault's theoretical framework in that it tends either to posit directly, or imply obliquely, 'historical succession and systematic replacement' of techniques of power, rather than the 'simultaneity and interconnectivity of heterogeneous technologies' (Lemke 2011: 74). Governance through biopower, even if taken as somehow not involving hegemony or discipline, can be 'but merely one element among others' (Foucault 1976/1998: 136).

Moreover, the supposed shift to post-hegemonic society is also premised on a fundamental and false binary between 'productive' and 'reproductive' activity between 'invention and discipline' in Lash's reckoning. He says: 'If the hegemonic order works through a cultural logic of reproduction, the post-hegemonic power operates through a cultural logic of invention, hence not of reproduction but of chronic production of economic, social and political relations' (2007: 56). This is also contrary to Foucault's ideas. Despite the distinction he may have drawn between discipline and regulatory population control in The History of Sexuality, in his model of power discipline is inherently productive, generating the knowledge categories, states of being and subjectivities inhabited by its subjects. Indeed he argues that it is only through such a productive capacity that a particular power relation can become established in liberal models of governance. It is an unfortunate consequence of the canonisation of the idea of a passage from conditions of 
confinement to one of biopolitical control (Mitropoulos 2012) that the creative capacities attributed to reproductive disciplining activity by Foucault have been lost.

But more importantly there is a historical inaccuracy in assuming that a clear division once existed between realms of sociality and those of capitalist accumulation, so that it is only now in the context of the social factory that power and economic relations are able to permeate the social and 'work from within' (Lash 2007: 59). As many feminist researchers and sociologists of economics have informed us, domination has never been confined solely to the realms of the social nor relations of production to those categories of activity organised around the wage relation. Throughout the history of capitalism there has been a necessary coexistence of affective, immaterial, biological and/or cognitive labour with those forms of work identified as 'productive' (see Dalla Costa \& James 1972; Fortunati 1995; Federici 2004; Zelizer 2005; Hochschild 1983/2003). The obvious example is that unpaid reproductive, affective domestic labour has provided the structural foundation upon which the capitalist economy has been built. The implication that capitalism has until recently impacted only within the walls of the factory denies the already social labour of women and men that has contributed directly and indirectly to capitalist relations. Feminist theories of labour tell us that it is certainly not new that power exerts itself through living matter and affective relations.

Yet, in discussions of contemporary biopolitics, it is quite common to see only a brief, perhaps token, mention of feminists such as Mariarosa Dalla Costa and Selma James who, in the words of Kathi Weeks (2011: 123), 'opened the door to a new conceptualization of the structure of capitalist social production, to which the category of the social factory was an early contribution'. Their contribution to understanding labour is typically raised and then dismissed in favour of a statement of the novelty of the social factory, both as a theoretical construct and as a lived reality. Thus, while I may have claimed earlier that Austerity Ireland functions as a social factory, the same is true of the 'Celtic Tiger' Ireland that predated and precipitated the economic collapse and of any precursor version of Ireland under capitalism (or indeed colonialism). Each has demanded and received the incorporation of various aspects of social life into its economic logic.

The dramatic growth of Ireland's Celtic Tiger years for instance was not only a fiscal project, but also involved the re-organisation of cultural and social norms (see Kirby et al. 2002; Coulter \& Coleman 2003). The entire social fabric was penetrated by the economic logic of that era and inevitably personal and domestic relations incorporated the social and cultural instabilities and personal desires demanded by the structures of high-finance capitalism. This involved an orientation away from the localised logics of established social institutions such as the Catholic Church to international markets and the entrepreneurial social, economic and physical mobility associated with them (O’Riain 2000: 183; Peillon 2002). Cultural norms perpetuated the desire for high levels of individual consumption and 
for the property ownership that fed Ireland's housing boom. Appropriate personal attitudes were also policed, with Taoiseach Bertie Ahern musing in a 2007 speech to the Irish Council of Trade Unions that he didn't understand people who were critical of the economy and wondered why they simply didn't commit suicide (RTÉ 2007). To live (at all) in the Celtic Tiger was to put your labouring body but also your desiring self uncritically to work in generating and perpetuating its economic logics. The same absorption of social, cultural and interpersonal life into the economic system is true of any socioeconomic formation in which base and superstructure mutually reinforce each other. As Ryan says of her studies of the life-choices of Irish people between 1999 and 2001, individual choices and economic values, public and private spheres, 'cannot be considered in isolation from each other' (2003: 155).

It is fundamentally false then to assert that the incorporation of biopower is an entirely contemporary phenomenon that, ipso facto, requires a radically transformed relation of power. When the already existing incorporation of bodies and subjectivities into capitalist regimes are taken into consideration, to suggest that regimes of biopower necessarily require the exertion of power or resistance in forms other than hegemony becomes untenable. Biopower and biopolitical control clearly have taken, and still can take, the form of hegemonic disciplinary power and counter-hegemonic struggle.

\section{Reproduction and Genealogy}

If hegemonic discipline is compatible, if not co-extensive, with governance of the social factory, and if consent is still necessary to establish and maintain a system of control, then we would do well to reinvigorate our investigation of these techniques and technologies of power. In particular it becomes important to understand hegemony as involving processes of subjectivation through which legitimacy is generated, maintained and normalised but which are not encountered as alien forces. It is to explore the Althusserian subject who is already implicated in ideology and 'fraught with the paradox of capture' (Beller 2013: 182; Althusser 1971/2008). In this I am echoing Mitropolous who, while recognising the important contributions made by Autonomist readings of Marx, also suggests a need to explore issues of restoration and reproduction in contemporary capitalism. She says that such analysis must be 'accompanied by closer attention to the specifically genealogical character of the persistence and/or re-imposition of capitalism, that is to say, of particular forms of sociality that are also the modes for the legitimate redistribution of property and right' (2012: 92).

Mitropoulos advocates continued investigation of those processes that assure generational lineage, a metaphor which, by drawing upon concepts of biological reproduction, focuses attention upon the reproduction of capital within familial, domestic relations: oikonomia. This reproduction is more than the generation of 
living creatures. It is also about the reproduction of subjectivities and the orientations conducive to the perpetuation of social roles, including 'demarcations of race, gender, sexuality and nation' (200) that constitute 'the productive labourer'. Mitropoulos draws our attention to a question associated clearly with the interrogation of hegemonic domination: what is being restored at the frontiers of capital? She depicts colonisation not as dispossession but as involving the installation of proper capitalist order over 'all those instances where the legibility of property rights is (or has become) acutely uncertain' (113). Wherever capital is reimposing limits, such as in the symbolic violence inflicted on non-compliant public sector workers in Ireland, it is demanding 'the restoration of genealogical lines, in their simultaneously sexual, legal and economic senses’ (113). The question then to be asked of political practices such as the imposition of and resistance to Austerity is

the extent to which they expand the conditionality of the genealogical or make other
ties viable. What forms of generation - beyond the genealogical nexus of race, sexu-
ality, citizenship, class and gender, that is, beyond the adhesions of desire to re-
/production of capitalism - might be furnished with plausible infrastructures in the
composition of political demands for reform or movements for radical transfor-
mation? (114).

While she does not use the term here, these questions are about tracing the mechanisms of hegemonic domination, legitimation and antagonism. For an activist politics, her framework begs us to ask what alternate subject positions or forms of agency are being articulated in the varied discourses of Austerity whose generative potential might be capitalised and expand upon for transformative purposes? A lead can be taken from Douzinas' (2013: 137-154) mapping of the various transformations of subjectivities in a range of anti-Austerity protests in Greece that attempts to understand how people came to temporarily or permanently abandon the control of biopolitical capitalism. In the Irish context, there are lessons to be learned from the emergence of a diverse, but organised, political agency within protests against public sector pay cuts, as well as the nature of the individual subjectivities collected within. Located outside the genealogical lineage of the Irish State, their own trade unions and widely mediated popular opinion, what moved these workers towards experiencing and expressing that resistance is important to understand. Did it emerge from an economic rationality as further pay cuts threatened lifestyles, or did the illegitimacy of dominant thinking develop from ideological, affective or even professional concerns, amplified by particular agents? Knowing this process will allow us to see how, when and why the reproduction of hegemonic ideas fails and so provide activists with tools for instigating such failure. It seems important to understand empirically how these individuals manifested a 'plausible infrastructure' of resistance, both materially and discursively. Tracing the generation of these subject positions will provide political ground 
from which further meaningful and urgent resistance can be stimulated and organised.

\section{The Return to Hegemony and Social Reproduction}

To return to questions of hegemony and social reproduction in this way is about recognising the embedding of all subjects in a rich array of cultural and social institutions that fundamentally shape that subjectivity and give form to political agency. It is about acknowledging the genealogical question of 'to whom and what we owe our existence' (Mitropoulos 2012: 93) rather than merely willing a return to a mythical autonomous, unified, self-possessed subject who exists prior to capitalism (or ideology generally) (Weeks 2007: 234). It is about identifying the dominant arrangements of power/knowledge in order to re-arrange them so we can generate new subject positions that articulate resistant politics.

And despite the exploration of acts of resistance here, a focus on the reproduction of hegemony also addresses how, despite assumptions about the emergence of progressive politics from multitude, a population can remain more or less complicit with economic and political regimes that damage society. This returns us to life in the social factory of Austerity Ireland and to the sense of failure Helena Sheehan finds in the passivity of the general population. To understand this political context, it is important to identify the mechanisms legitimating hegemonic ideas and perpetuating consent. An obvious site to explore is the astonishingly complicit mainstream broadcast and print media of Ireland in which state economic orthodoxy is rarely challenged and which provide an ideal site for the reproduction of Austerity ideologies. It may be possible to relate the colonial legacy of social and economic dependence on higher-order cultural institutions such as the Catholic Church to the widespread compliance with now secular equivalents such as the Troika. The deep enmeshing of Catholic morality in everyday Irish life and social systems may be that which enables claims that 'we all partied' to effectively chasten and discipline a population. It may also be possible to identify the less intense material immiseration felt by middle-class Irish citizens relative to their Greek counterparts to account for disparities in the intensity and extensity of struggle against Austerity's economic logic. Which of these socio-historical, socio-economic and cultural conditions, or combinations of any or all, have produced the hegemonic legitimacy of Austerity Ireland is not entirely clear and much more extensive investigation than I can offer in this theoretical critique would be required to grasp the inter-related mechanics that have produced the relatively compliant subjects of contemporary Ireland.

What is clear though is that to attempt to understand the politics of Irish Austerity without recourse to the concept of disciplining hegemony is to fail to understand them in their specificity, or to provide useful grounds for intervention. The concept of multitude fails to provide access to mechanisms for motivating social 
change outside of the elusive properties of emergence within the general intellect (Camfield 2007; Thorburn 2012). For those like Sheehan who are urgently seeking to mobilise a vulnerable population to bring about material political change, this is too much of a tenuous proposition on which to hang such pressing hopes. Identifying mechanisms of social reproduction as proposed above draws attention to sites where that reproduction is incomplete or partial and which therefore can be leveraged in antagonistic struggle. But this can only happen when we discard the concept of post-hegemony and immanent control and instead understand the affective and logical genealogies of contemporary political subjects. Further empirical interrogation of the incomplete reproduction of dominant ideology, as it is manifesting in the alliance of Irish public sector workers for instance, can offer insight into how and when cracks in legitimating discourses appear and how those fissures can be rearticulated and organised in the production of counterhegemonic narratives and, ultimately, of effective resistance to Austerity. We need to ask not only how subjects are produced but, after that, how they may be alternatively articulated. Such work is vital for those of us seeking to manifest change in the economic politics of Austerity.

Finally, I want to assert that the renewed focus on mechanisms of social reproduction advocated here should not be dismissed as 'merely cultural' analysis. Drawing a cue from Butler (1997), I want to reject the implication that understanding processes of subjectivation is somehow not properly Marxist or nothing to do with economic equity and the redistribution of material resources. The production of subjectivity is elemental in maintaining the structures of capitalism and there are profound material consequences and causes of the various subject positions we (are called upon to) occupy as citizens, consumers, activists, workers, individuals, family members, etc. As Johnson (2007: 99) says: 'Hegemony is not about cultural politics only. There can be no rule by cultural means alone. Yet culture enters into every move of the powerful or those who seek emancipation.' The failure to recognise that the social factory, and the contributions to capital this term encompasses, has a very long history has obscured the entwined relationship of material conditions and symbolic frameworks. Attendance to the practices of hegemonic power and the regimes of legitimacy within a culture forms part of a materialist analysis and is just as urgent in the biopolitical social factory as ever. It is certainly necessary in Austerity Ireland.

Dr. Kylie Jarrett is Lecturer at the Centre for Media Studies at the National University of Ireland Maynooth. She has recently published Google and the Culture of Search with Ken Hillis and Michael Petit and is currently using feminist labour theories to explore consumer activity in digital media. E-mail: kylie.jarrett@nuim.ie 


\section{References}

Althusser, Louis (1971/2008): On Ideology, London: Verso.

Arditi, Benjamin (2007): 'Post-hegemony: Politics Outside the Usual Post-Marxist Paradigm', Contemporary Politics, 13:3, 205-226.

Atzert, Thomas (2006): ‘About Immaterial Labor and Biopower’, Capitalism Nature Socialism, $17: 1,58-64$

Beer, David (2009): 'Power Through the Algorithm? Participatory Web Cultures and the Technological Unconscious', New Media \& Society, 11:6, 985-1002.

Beller, Jonathan (2013): 'Digitality and the Media of Dispossession', Trebor Scholz (ed.): Digital Labor: The Internet as Playground and Factory, Oxon: Routledge, 165-186.

Brennan, Donagh (2010): 'As the Story is Told: There is No Alternative', Politico.ie, 30 November: http://politico.ie/index.php?option=com_content\&view=article\&id=6956:as-the-story-istold-there-is-no-alternative\&catid=257:there-is-no-alternative\&Itemid=1064 (accessed 14 January 2014).

Burke, Sara (2010): 'Boom to Bust: Its Impact on Irish Health Policy and Services', Irish Journal of Public Policy, 2:1: http://publish.ucc.ie/ijpp/2010/01/burke/08/en (accessed 14 January 2014).

Butler, Judith (1997): 'Merely Cultural', Social Text, 15:3-4, 265-277.

Camfield, David (2007): 'The Multitude and the Kangaroo: A Critique of Hardt and Negri’s Theory of Immaterial Labour', Historical Materialism, 15, 21-52.

Caritas Europa (2013): The Impact of the European Crisis, http://www.caritaseuropa.org/code/en/publications.asp (accessed 14 January 2014).

Coulter, Colin \& Steve Coleman (eds) (2003): The End of Irish History? Critical Reflections on the Celtic Tiger, Manchester: Manchester University Press.

Dalla Costa, Mariarosa \& Selma James (1972): The Power of Women and the Subversion of the Community, London: Falling Wall Press.

Deleuze, Gilles (1995): Negotiations: 1972-1990, New York: Columbia University Press.

Douzinas, Costas (2010): 'The Greek Tragedy', Critical Legal Thinking, 17 November, http://criticallegalthinking.com/2010/11/17/the-greek-tragedy/ (accessed 14 January 2014).

----(2013): Philosophy and Resistance in the Crisis, Cambridge: Polity Press.

Dunphy, Shane (2013): 'In the Classroom, "Reforms” Do Not Spell Improvements', Irish Independent, 29 September, http://www.independent.ie/opinion/analysis/shane-dunphy-in-theclassroom-reforms-do-not-spell-improvements-29618442.html (accessed 14 January 2014).

Dyer-Witheford, Nick (1999): Cyber-Marx: Cycles and Circuits of Struggle in High-technology Capitalism, Urbana and Chicago: University of Illinois Press.

Dyer-Witheford, Nick \& Greig de Peuter (2009): Games of Empire: Global Capitalism and Video Games, Minneapolis: University of Minnesota Press.

Federici, Silvia (2004): Caliban and the Witch: Women, the Body and Primitive Accumulation, New York: Autonomedia.

Fortunati, Leopoldina (1995): The Arcane of Reproduction: Housework, Prostitution, Labour and Capital, New York: Autonomedia.

Foucault, Michel (1976/1998): The Will to Knowledge: The History of Sexuality: 1, London: Penguin.

----- (1984/1992): The Use of Pleasure: The History of Sexuality: 2, London: Penguin.

----- (1984/1990): The Care of the Self: The History of Sexuality: 3, London: Penguin.

-----(2008): The Birth of Biopolitics: Lectures at the College de France 1978-1979, Michel Senellart (ed.), Basingstoke, Hampshire: Palgrave Macmillan.

Fuchs, Christian (2008): Internet and Society: Social Theory in the Information Age, New York and London: Routledge.

Gregg, Melissa (2011): Work's Intimacy, Cambridge: Polity Press.

Hardt, Michael \& Antonio Negri (2000) Empire, Cambridge, MA: Cambridge University Press.

----- (2005): Multitude, London: Penguin.

------(2009): Commonwealth, Cambridge, Mass: Harvard University Press. 
Hochschild, Arlie (1983/2003): The Managed Heart: Commercialization of Human Feeling, Berkeley and LA: University of California Press.

The Irish Times (2012): ‘Mortgage Arrears Increase Again’, 13 December, http://www.irishtimes.com/newspaper/breaking/2012/1213/breaking16.html (accessed 14 January 2014).

------(2013): 'The Debt Deal Dilemma', 19 February, http://www.irishtimes.com/debate/the-debtdeal-dilemma-1.1253144 (accessed 14 January 2014).

Johnson, Richard (2007): 'Post-Hegemony? I Don’t Think So’, Theory, Culture \& Society, 24:3, 95-110.

Kennedy, Sinead (2011): ‘Discipline and Punish’, Crisis Jam, Politico.ie, 5 December, http://politico.ie/crisisjam/8122-state-were-in-discipline-and-punish.html (accessed 14 January 2014).

Kirby, Peader, Luke Gibbons \& Michael Cronin (eds) (2002): Reinventing Ireland: Culture, Society and the Global Economy, London: Pluto Press.

Lash, Scott (2007): 'Power after Hegemony: Cultural Studies in Mutation?' Theory, Culture \& Society, 24:3, 55-78.

Lazzarato, Maurizio (1996): 'Immaterial Labor', Paolo Virno \& Michael Hardt (eds) Radical Thought in Italy: A Potential Politics, Minneapolis: University of Minnesota Press, 133-146.

Lemke, Thomas (2011): Biopolitics: An Advanced Introduction, New York: New York University Press.

Malone, Noel (2013): 'Education People: A Principal's View of the Action', The Irish Times, 7 October 2013: http://www.irishtimes.com/news/education/education-people-a-principal-s-viewof-the-asti-action-1.1550736 (accessed 14 January 2014).

McGuire, Peter (2013): ‘Hey, Teachers', The Irish Times, 28 September 2013: http://www.irishtimes.com/news/education/hey-teachers-1.1542731 (accessed 14 January 2014).

McStay, Andrew (2011): 'Profiling Phorm: An Auto-Poietic Approach to the Audience-asCommodity', Surveillance \& Society, 8:3, 310-322.

MerrionStreet.ie (2013): 'Significant Impact of Gathering Ireland 2013 Outlined at Global Irish Economic Forum’, 4 October 2013: http://www.merrionstreet.ie/index.php/2013/10/significantimpact-of-gathering-ireland-2013-outlined-at-global-irish-economic-forum/?cat=67 (accessed 14 January 2014).

Mitropoulos, Angela (2012): Contract \& Contagion: From Biopolitics to Oikonomia, New York: Minor Compositions.

Mylonas, Yiannis (2012): 'Media and the Economic Crisis of the EU: The "Culturalization” of a Systemic Crisis and Bild-Zeitung's Framing of Greece’, tripleC: Communication, Capitalism \& Critique, 10:2, 646-671, http://www.triplec.at/index.php/tripleC/article/view/380 (accessed 14 January 2014).

Negri, Antonio (1989): The Politics of Subversion: A Manifesto for the Twenty-first Century, Cambridge: Polity Press.

O’Regan, Michael (2013): ‘Quinn Warns Teachers They are Endangering Job-for-life Status’, The Irish Times, 25 September 2013: http://www.irishtimes.com/news/ireland/irish-news/quinnwarns-teachers-they-are-endangering-job-for-life-status-1.1538783 (accessed 14 January 2014).

O’Riain, Sean (2000): 'The Flexible Developmental State: Globalization, Information Technology, and the "Celtic Tiger”, Politics \& Society, 28:2, 157-193.

O’Rourke, Colm (2013): 'Haddington Road Only Way Out of Chaos', Irish Independent, 6 October 2013: http://www.independent.ie/opinion/columnists/colm-orourke/haddington-road-onlyway-out-of-chaos-29637606.html (accessed 14 January 2014).

Oxfam (2013): The True Cost of Austerity and Inequality: Ireland Case Study, Oxfam.org, September, http://www.oxfamireland.org/blog/austerity (accessed 14 January 2014).

Peillon, Michel (2002): 'Culture and State in Ireland’s New Economy’, Peader Kirby, Luke Gibbons \& Michael Cronin (eds): Reinventing Ireland: Culture, Society and the Global Economy, London: Pluto Press, 38-53. 
Politico.ie (2010): 'There is No Alternative', 30 November 2010:

http://politico.ie/index.php?option=com content\&view=category\&layout=blog\&id=257\&Itemi d=1064 (accessed 14 January 2014).

Pope, Conor (2013): ‘Keys, Please’, The Irish Times, 23 March 2013: http://www.irishtimes.com/life-and-style/homes-and-property/keys-please-1.1335911 (accessed 14 January 2014).

Ross, Andrew (2013): 'In Search of the Lost Paycheck', Trebor Scholz (ed.): Digital Labor: The Internet as Playground and Factory, Oxon: Routledge, 13-32.

RTÉ (2007) 'Ahern apologises for suicide remark', RTÉ News, 4 July 2007, http://www.rte.ie/news/2007/0704/90808-economy/ (accessed 14 January 2014).

Ryan, Anne B. (2003): 'Contemporary Discourses of Working, Earning and Spending: Acceptance, Critique and the Bigger Picture', Colin Coulter \& Steve Coleman (eds) The End of Irish History? Critical Reflections on the Celtic Tiger, Manchester: Manchester University Press, 155-174.

Sheehan, Helena (2013): 'To the Crucible: An Irish Engagement with the Greek Crisis and the Greek Left', Greek Left Review, 23 January 2013: http://greekleftreview.wordpress.com/2013/01/23/to-the-crucible-an-irish-engagement-with-thegreek-crisis-and-the-greek-left/ (accessed 14 January 2014).

Swiffen, Amy (2009): 'From Hegemony to Biopolitics', Review of Education, Pedagogy and Cultural Studies, 31:2-3, 237-252.

Terranova, Tiziana (2000): 'Free Labor: Producing Culture for the Digital Economy', Social Text, 18:2, 33-58.

Thoburn, Nicholas (2007): 'Patterns of Production: Cultural Studies After Hegemony', Theory, Culture \& Society, 24:3, 79-94.

Thorburn, Elise Danielle (2012): 'A Common Assembly: Multitude, Assemblies, and a New Politics of the Common', interface, 4:2, 254-279.

Titley, Gavan (2013): 'Budgetjam! A Communications Intervention in the Political-Economic Crisis in Ireland', Journalism, 14:2, 292-306.

Venn, Couze (2007): 'Cultural Theory, Biopolitics, and the Question of Power', Theory, Culture \& Society, 24:3, 111-124.

Virno, Paolo (2004): A Grammar of the Multitude, LA: Semiotext(e).

Wall, Martin (2013): 'ASTI Rejects Haddington Road Deal, Backs Industrial Action but TUI Accepts', The Irish Times, 20 September 2013: http://www.irishtimes.com/news/education/astirejects-haddington-road-deal-backs-industrial-action-but-tui-accepts-1.1534718 (accessed 14 January 2014).

Weeks, Kathi (2007): 'Life Within and Against Work: Affective Labor, Feminist Critique, and Post-Fordist Politics’, ephemera, 7:1, 233-249.

----- (2011): The Problem with Work: Feminism, Marxism, Antiwork Politics and Postwork Imaginaries, Durham and London: Duke University Press.

Workers' Solidarity Movement (2013): 'The Human Cost of Cuts to the Public Services Thoughts of a Public Sector Worker', 20 March 2013, http://www.wsm.ie/c/human-cost-cutspublic-services-worker (accessed 14 January 2014).

Zelizer, Viviana A. (2005): The Purchase of Intimacy, New Jersey: Princeton University Press. 